\title{
The Science of Disaster Medicine: From Response to Risk Reduction
}

\section{Afet Tıbbı Bilimi: Müdahaleden Risk Azaltmaya}

\author{
(D) Huseyin KOCAK1, (1) Kerem KINIK 2,3, (1) Cuneyt CALISKAN33, (1) Kurtulus ACIKSARI4
}

${ }^{1}$ Canakkale Onsekiz Mart University Faculty of Health Science, Department Emergency Aid and Disaster Management, Canakkale, Turkey 2University of Health Sciences Turkey, Institute of Hamidiye Health Sciences, Department of Disaster Medicine, Istanbul, Turkey

3University of Health Sciences Turkey Hamidiye Faculty of Health Sciences, Department of Emergency Aid and Disaster Management, Istanbul, Turkey ${ }^{4}$ Istanbul Medeniyet University Faculty of Medicine, Department of Emergency Medicine, Istanbul, Turkey

\begin{abstract}
The scientific advancement of the disaster medicine concept started approximately five decades ago. Different disciplines, such as public health, emergency health services, emergency medicine, and military medicine, work within the disaster medicine framework. Disaster medicine aimed to ensure that health services and facilities are operational both in the pre- and post-disaster periods to prevent and reduce the negative health circumstances of the society facing disaster risks. It is a discipline with slow scientific progress due to unclearly systematized multidisciplinary structure and sub-study areas. However, important targets regarding the field of disaster medicine were indicated in the Sendai Framework for Disaster Risk Reduction 2015-2030 published by the United Nations. Among the global goals of disaster medicine, are to reduce the number of deaths and injuries, reduce the number of affected people, strengthen critical facility infrastructure, and ensure functional sustainably of these facilities during disasters. To achieve these goals, disaster medicine is expected to rapidly develop both institutionally and academically. Disaster medicine is a global, mass, administrative, and doctrinal discipline that means beyond clinical studies. Particularly, the development and dissemination of disaster medicine education were emphasized for the first time with the Sendai Framework for Disaster Risk Reduction, which was determined globally in 2015. The disaster medicine discipline is seen to reach a very strong point by 2030.
\end{abstract}

Keywords: Disaster management, disaster medicine, public health, resilience, risk reduction

\section{öz}

Afet tıbbı kavramının bilimsel gelişimi dünyada yaklaşık 50 yıl önce başlamıştır. Halk sağlığı, acil sağlık hizmetleri, afet yönetimi, acil tıp ve askeri tıp gibi farklı disiplinlerin afet tıbbı kavramı çerçevesinde çalışmalar yaptığı görülmektedir. Afet tıbbının amacı, afet riskleri bulunan toplumun kötü sağlık şartlarını önlemek ve azaltmak için afet öncesi dönemde afet risk yönetimi ve afet sonrası dönemde sağlık hizmetleri ve tesislerini çalışır durumda olmasını sağlamaktır. Çok disiplinli yapısı ve halen net bir şekilde alt çalışma konularının sistematize edilememesi nedeniyle bilimsel ilerlemesi oldukça yavaş bir şekilde gelişen bir disiplindir. Ancak afet tıbbı alanına yönelik Birleşmiş Milletler tarafından 2015-2030 dönemi için yayınlanan Sendai Afet Risk Azaltımı Çerçeve Eylem Planı'nda önemli hedefler bulunmaktadır. Afet tıbbı açısından küresel hedefler arasında yer alan ölüm ve yaralanma sayılarının azaltılması, etkilenen insan sayısının azaltılması, kritik tesislerin alt yapılarının güçlendirilmesi ve afetlerde sürdürülebilir bir şekilde fonksiyonlarına devam edebilmesi yer almaktadır. Bu hedeflerin gerçekleştirilebilmesi için kurumsal ve akademik olarak afet tıbbının hızlı bir şekilde gelişmesi beklenmektedir.

Afet tıbbı disiplini klinik çalışmaların ötesinde bir anlam ifade eden küresel, kitlesel, yönetimsel ve doktrinsel bir disiplindir. Özellikle 2015 yılında küresel olarak belirlenen Sendai Afet Risk Azaltımı Çerçeve Eylem Planı ile ilk defa afet tıbbı eğitiminin geliştirilmesi ve yaygınlaştııılması vurgulanmaktadır. 2030 yılına gelindiğine afet tıbbı disiplinin çok güçlü bir noktaya geleceği görülmektedir.

Anahtar kelimeler: Afet yönetimi, afet tıbbı, halk sağlığı, dirençlilik, risk azaltma 


\section{The Concept of Disaster Medicine}

The necessary scientific basis for disaster medicine and disaster health concepts is still debated in the literature!. Disaster medicine and disaster health concepts are often interchangeably used. Discussions on the preferred concept are still being held. In this paper, the disaster medicine concept is used instead of the disaster health concept. Disaster medicine is a discipline consisting of a combination of studies in emergency health services, emergency medicine, disaster management, and public health ${ }^{2.3}$. According to Gunn ${ }^{4}$, disaster medicine "works and practices in cooperation with other disaster management important health disciplines (epidemiology, emergency medicine, public health, pediatrics, social medicine, international health, etc.) to prevent, promptly respond, and rehabilitate health problems caused by disasters". In another definition, disaster medicine is a new and comprehensive ${ }^{5}$ discipline as it is a very broad field of practice and research that includes medical disciplines, such as emergency medicine, traumatology, and public health, as well as disaster management, which covers non-medical issues, such as communication, logistics, and transport ${ }^{6}$. Disaster medicine is a field of specialization that requires special training in interacting with many different institutions working on disasters ${ }^{2}$. According to Eryilmaz ${ }^{7}$, it is the field of medicine that focuses on the disproportion between the health needs of the affected society and the available resources of the affected community to save the highest number of injured.

It is a very crucial discipline, especially with the upsurge of mass injuries, terrorism, and public health emergencies in recent years ${ }^{8}$. The need for scientific principle application in disaster studies was first defined by the forerunners of disaster medicine; however, studies in this field are developing very slowly'. Additionally, disaster medicine is a strong multidisciplinary field; however, the lack of practical understanding of people from different backgrounds hinders its development ${ }^{9}$. Disasters reduce the delivery of health services by negatively affecting the infrastructure of health facilities in the affected areas. Therefore, business continuity planning and management should be included in emergency planning for the uninterrupted health services continuation. Efforts are made to strengthen and expand health system capacity before disasters. These studies consist of practices, such as hospital structural strengthening, special training of healthcare staff on disasters, planning and exercise studies, and strengthening infrastructure.
After disasters, the most important service in the acute and long-term is health care. Understanding the disaster medicine principles are vital for all healthcare personnel to accurately and effectively respond to disasters. Learning their role is essential for health staff, especially regarding medical intervention in many different types of events ${ }^{2}$. The discipline of disaster medicine is formed by the integration of studies in the fields of public health, emergency health services, patient care services (hospitals), definitive treatment centers (private centers, advanced hospitals, and university hospitals), and disaster management (Figure 1) ${ }^{10}$. Therefore, the processing principles and practices of all these areas before, during, and after disasters are issues that should be dealt with scientifically and systematically in terms of disaster medicine.

\section{History of Disaster Medicine}

The disaster medicine concept, like the disaster management concept, has its roots in military institutions". However, this paper discussed only civilian studies in a historical context. Today, disaster medicine has developed as an essential part of human medicine. In the $20^{\text {th }}$ century, different investigations were conducted to respond to big explosions in mines, railway tunnels, and factories ${ }^{12}$. Necessary scientific standard application in the field of disaster medicine was defined by the forerunners of the field nearly 50 years ago; however, the science of disaster health and medicine continues to slowly develop today! Among the most significant reasons for this situation are the inability to control the variable quantities in the field due to the nature of disasters, high-risk studies, and specialized staff shortage in the field of disaster medicine.

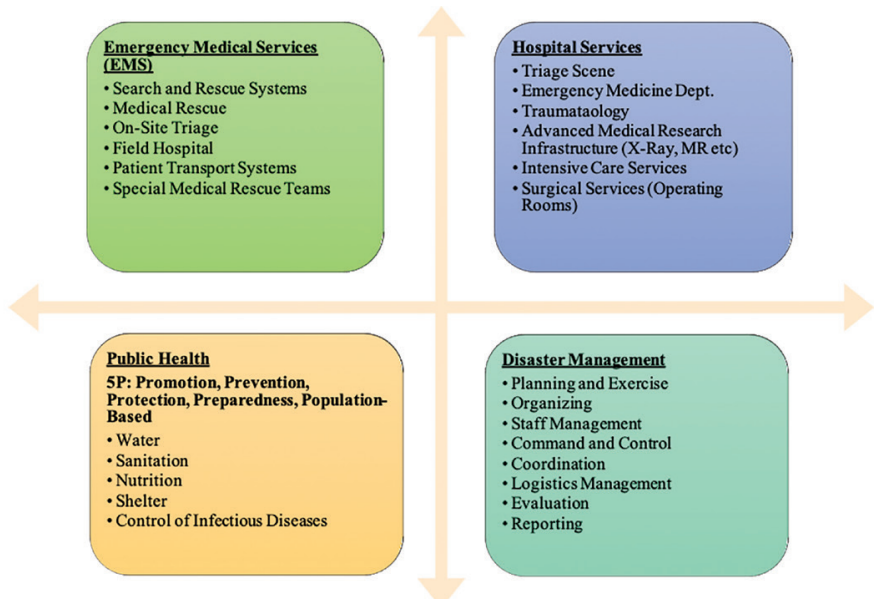

Figure 1. Basic components and functions of disaster medicine.

MR: Magnetic resonance 
It was established as a discipline in the early $1980 \mathrm{~s}^{12}$. To historically analyze disaster research, critical examination of the length of disaster perception. Therefore, before starting the study, the differences between concepts such as disaster, accident, crisis, and event should be clearly explained. In 1973, the first international disaster medicine Congress was held in Mainz, Germany 5 .

The International Society of Disaster Medicine, founded in $1975^{13}$, and the World Association for Disaster and Emergency Medicine (WADEM) were established as professional associations on October 2, 1976, to develop global studies on pre-hospital and emergency health services, public health, disaster health, and preparedness ${ }^{14}$. WADEM is the oldest disaster medicine organization, with governmental or non-governmental members from 55 different countries in the fields of medicine, nursing, emergency management, academia, military, veterinary medicine, psychology, and sociology $y^{13}$. One of the key works of WADEM is the European Master in disaster medicine. This program started taking its first students in $2000 / 2001$. The objective of the program is to provide students with the ability to conduct scientific studies on the medical aspects of disasters by learning concepts and developments related to preparedness and management in disaster medicine ${ }^{15}$. In 2003, the first graduate program in the field of disaster medicine in Turkey was opened by the Department of Public Health, Institute of Health Sciences, Hacettepe University ${ }^{16}$. The first Ph.D. program in the field of disaster medicine was established in 2014 within the body of the Institute of Health Sciences at Bezmialem University". In 2018, a Ph.D. program in "Global Health, Humanitarian Aid, and Disaster Medicine" was started by Vrije University (Belgium/Brussels) through the emergency and disaster medicine Research Group and by Università del Piemonte Orientale (Italy) through the emergency and disaster medicine research center. Necessary development for disaster medicine as a formal discipline was discussed worldwide for a long time. Scientific studies around the concept of disaster medicine by scientists and organizations working in this field are increasing daily. In 2020, MA and Ph.D. programs in "disaster medicine" were opened by Hamidiye Institute of Health Sciences, University of Istanbul Health Sciences in Turkey ${ }^{18}$, whereas MSc and Ph.D. programs in "Pre-Hospital Emergency Health Services and Disaster Management" in the field of disaster medicine were opened by the Institute of Health Sciences, Ege University ${ }^{19}$.

\section{The Objective of Disaster Medicine}

Disaster medicine aimed to carry out disaster risk management studies in the pre-disaster period to prevent and reduce the direct and indirect effects on the health of the society affected by disasters and ensure that health services and facilities are operational in the postdisaster period ${ }^{9}$, as well as transform health services into a resilient structure at the local, regional, and national level so that the highest number of people can benefit from scarce resources. Disaster medicine aimed to create a strong emergency health services system in the pre-hospital area, especially those working in the field, unlike health services in the usual processes. One of the most important concepts in disasters is the fluctuation/ expansion of institutional resources in terms of capacity.

Rescue teams are necessary to treat the sick and injured in adverse environmental conditions in the disaster area. Implementation and research activities of health services related to emergency medical rescue and disaster relief activities are among the basic duties of disaster medicine ${ }^{20}$. Disaster medicine generally deals with natural disasters, such as earthquakes, floods, landslides, and storms, as well as human-made disasters. Accidents and terrorist attacks in chemical, biological, radiological, and nuclear fields are among the study areas of disaster medicine ${ }^{21}$, as well as complex humanitarian emergencies, such as migration and civil unrest.

\section{Disaster Medicine Objectives}

The main purpose of disaster medicine is to prevent and reduce the negative effects of disasters on public health, ensure that the health system effectively responds during disasters, restore health conditions to pre-disaster status, and protect or re-establish health services and institutions ${ }^{22}$.

\section{Disaster Medicine Components}

Disaster Epidemiology: It refers to the epidemiological assessment of short- and long-term adverse health effects of disasters and prediction of the consequences of future disasters (Center for Disease Control and Prevention). In disaster medicine, disaster epidemiology is critical in managing all processes before, during, and after disasters. The most important focus of the basic public health principles in the field of disaster medicine is disaster epidemiology. Disaster environments must have a unique structure, and information must be systematically retained and accumulated over time. Creating scientific 
knowledge on disaster management processes with descriptive and observational studies is necessary. Studies are generally observational because controlling variables in real disaster situations is almost impossible ${ }^{23}$.

Disaster Medicine and Public Health: The Protection, prevention, promotion, preparedness, and populationbased approach, which are the basic public health principles, constitutes the basic philosophy of risk management studies of disaster medicine ${ }^{10,24}$. In addition, roles and responsibilities are present in the intervention phase of social and institutional clean water supply, nutrition, shelter, infectious disease control, environmental health, occupational health, and safety, which is closely related to disaster medicine in the holistic integration of public health study areas into disaster management studies. The studies carried out in the recovery period are related to health support and improvement ${ }^{23}$.

Disaster Medicine and Emergency Medicine: Although it concerns all medical disciplines in hospitals, which are the definitive treatment centers of health services, the closest and most related discipline is emergency medicine. Emergency medicine is the first point of contact for the pre-hospital field ${ }^{25}$. Therefore, emergency medicine is the focal point of disaster medicine in the hospital. In disaster medicine, clinical skills of emergency medicine are needed.

Disaster Medicine and Pre-hospital Emergency Health Service: As a study area, emergency health services contain quite different risks from other health areas. They function as a kind of life-saving, emergency medical intervention system in displacement conditions ${ }^{26}$. The nature of disaster medicine exceeds the routine health system capacity, thus providing health services in the field is naturally essential. For instance, field hospital establishment and specially trained health team creation to save lives in high-risk conditions. Therefore, disaster medicine attempts to establish a resilient system within the context of emergency health services.

Disaster Medicine and Disaster Management: Unlike other clinical medicine fields, disaster medicine covers disaster management topics, including risk assessment, disaster planning, drills, disaster logistics, and decisionmaking strategies.

\section{Characteristics of Disaster Medicine ${ }^{5}$}

Due to the nature of disaster events, many variables are rarely controllable'. Health services are of fundamental value in the prevention, preparedness, and response stages of disasters ${ }^{27}$. The working disaster medicine principles are quite different from those of normal times. The characteristics of disaster medicine include the following:

(1) Disaster Medicine and Planning: In addition to the planning of emergency events, comprehensive planning is made by emergency aid and disaster management specialists, including business continuity and health organization administration ${ }^{27}$. Many disasters and mass accidents have short-, medium-, and long-term negative effects on human health, placing a considerably higherthan-normal health system burden ${ }^{20}$. Disaster plans and management to encounter these challenges have complex structures. Generally, emergency and disaster plans are made for the effective and efficient use of local, regional, and national resources. Strengthening the response capacity at the provincial level and planning, exercising, and learning lessons will increase resilience, which will consequently lead to better responses. Mobilizing professional healthcare equipment and resources or providing long-term health care in the disaster area is necessary based on hazard type and severity ${ }^{27}$. All prepared plans should be periodically tested with theoretical and field exercises.

(2) First Aid: Disasters are complex events in which mass injuries occur. These events require a large number of rescue teams. Therefore, first aid is the most important intervention until the rescue teams arrive. Corresponding to the post-earthquake data in Armenia, 90\% of the wounded were saved in the initial 3 hours and $50 \%$ in the first 6 hours. The first 72 hours after an earthquake are described as the golden hours for rescue efforts ${ }^{5}$.

(3) Field of Specialization/Operational: Disaster medicine is a specialty area that focuses on providing leadership in the field of emergency aid and rescue as part of the health system for disaster preparedness, disaster planning processes, and response studies to protect the process and community health related to all processes of health services throughout the disaster cycle $^{22}$. It differs from other disciplines since it requires unique working conditions and principles not found in normal health practices. As the base doctrine of disaster medicine, it provides information, guidance, and expertise for healthcare facilities, communities, public, and private sectors, focusing on the use of scarce resources. Therefore, emergency health services is a separate area of expertise as a combination of emergency medicine, public health, and disaster management disciplines ${ }^{10,28}$.

(4) Temporary Organization: During disasters, a medical team is usually sent to the disaster site, providing 
comprehensive urgent health response in 12 hours or less. Therefore, emergency medical teams (EMT) are in a mobilized structure.

(5) Unstable Work Environments: A temporary EMT is usually formed when assigned. However, special medical teams are established to prepare merely for disasters. These teams operate in high-risk and highly volatile environments. Therefore, the team must quickly adapt to the environment.

(6) Mass Losses: An enormous number of people might be lost within a brief period in disasters, such as floods, earthquakes, volcanic eruptions, explosions, and tsunamis.

(7) Triage: Disaster medicine aims to save the lives of the sick and injured, as much as possible, with insufficient resources. Therefore, triage is thought of as a central word in the field of disaster medicine. The word triage has originated from the French language meaning selection and separation. It is the earliest and essential phase in the medical response to a disaster ${ }^{29}$, aimed at saving the lives of the highest number of injured with scarce resources.

(8) Mass Injuries Causing Multiple Injuries: Some events cause extremely serious physical injuries in the disturbed area. Special treatment methods and longterm hospital health care are required in the definitive treatment process of these wounds. Crush syndrome and acute kidney failure, which are frequently encountered after earthquakes, are examples. A large number of burn injuries can be encountered when fires occur after an earthquake.

(9) Non-medical Characteristics: Disaster medicine requires the ability to implement, command, control, and coordinate outside of the medical discipline. It incorporates many characteristics of management science such as command, coordination, planning, exercise, strategy, administration voluntary management, and economic sustainability ${ }^{22}$. Therefore, it works in close cooperation with the disaster management system.

(10) Disaster Medicine Doctrine: Disaster medicine is a doctrinal field of medicine, which must respond in a planned manner to mitigate the disaster impact and provide care to the largest number of potential survivors. As a sub-part of the general disaster plan, disaster medicine plans should include all aspects of health care. The disaster medicine doctrine is to make emergency medical response studies a part of relief operations and make it a routine health service as soon as possible ${ }^{22}$.

\section{Disaster Medicine and Risk Reduction in Disasters}

Due to natural and technological disasters, individual and societal health is adversely affected physically, socially, psychologically, and economically ${ }^{30}$. Disasters are complicated incidents, leading to quick and multidimensional emergency medical services in the acute period and public health and psychosocial challenges in the extended term ${ }^{3}$. Due to natural disasters, 1.2 million people lost their lives in the last 20 years (2000-2019), and over 4 million people were affected by disasters ${ }^{31}$. The disasters experienced in this period caused an economic loss of approximately 3 trillion dollars. Disasters pose more and more risks to people in every aspect daily. Among the factors that increase disaster risks are as follows: rapid population growth in the last era, increased industrialization, hazards from technology advancement (e.g., nuclear capacity, cyber technology, biological risks, and chemical risks), climate crisis, migration, increased inequality between countries, and decreased natural resources. The main objective in combating disasters is to prevent living creatures from being harmed. This struggle requires an interdisciplinary approach ${ }^{16}$. Today, the "Integrated Disaster Management System," which is comprehensive and considers all hazards, is widely used in disaster management. This system consists of mitigation, preparedness, response, and recovery phases ${ }^{2}$. However, different disaster risk management models deal with the functional aspects of the traditional disaster management model (Figure 2) $)^{32,33}$.

The key factor in disasters is the individuals. Therefore, one of the most valuable areas before, during, and after the disaster in the field of health. Disasters both directly and indirectly affect the health of individuals and

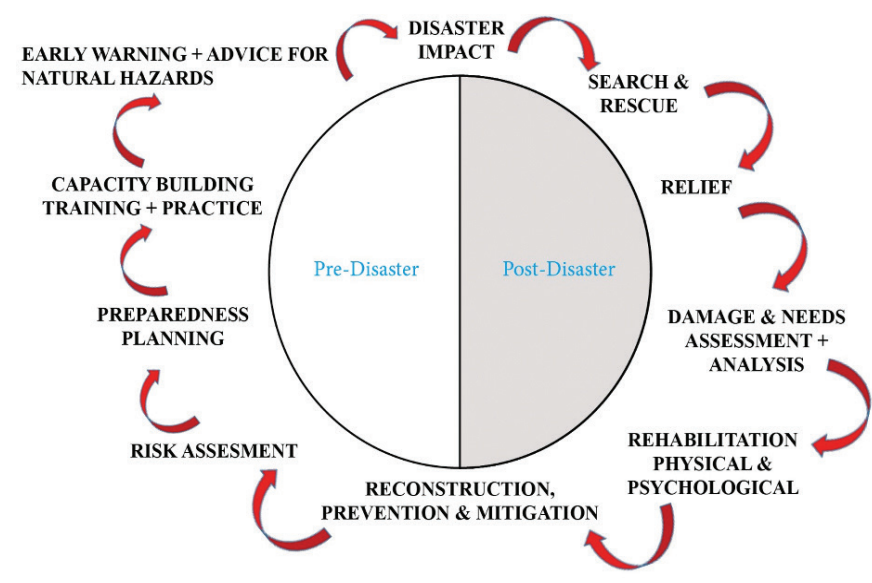

Figure 2. Disaster risk management concept. 
communities in a negative fashion ${ }^{34}$. Direct health effects include injury, disability, or death, whereas indirect health effects include health facility structural damages and damage or collapse of water, electricity, natural gas, and other service sectors.

The part of the health sector in disaster planning was traditionally evaluated as responding to emergencies ${ }^{34}$. This approach is very important in reducing post-disaster injuries and deaths. However, multi-sectoral disaster risk reduction strategies also give the health sector a comprehensive and proactive role in building better resilience to disasters ${ }^{28}$. Prevention, protection, and mitigation studies for hazards are required to effectively and sustainably use the capabilities and capacity of health services in the pre-disaster period within the scope of this role. Proactive studies are evaluated within the scope of public health protection and improvement. For example, after the 1999 Marmara earthquake, the Istanbul Seismic Risk Mitigation and Emergency Preparedness Project (ISMEP) was initiated in Istanbul to reduce disaster risks. In the field of disaster medicine, 48 hospital buildings and 59 polyclinics and health center buildings were strengthened against earthquakes in the ISMEP. Three of Istanbul's largest hospitals were completely demolished and rebuilt with seismic isolator technology. For National Medical Rescue Teams, vaccine, blood and blood products transport vehicle, various medical first response equipment (stretches, splint sets, rescue vests, etc.), storage containers, battery and diesel forklifts, mobile generator and light towers, cold storage, and many investments were made, such as a mobile communication vehicle, analog radio regional transmitters, analog radio central units, and analog radio mobile relays investments.

The field of health is the most needed study area during and after disasters. However, in the face of disasters, the health infrastructure and works are primarily affected.

Disaster risk reduction strategies and the health sector have a deep relationship ${ }^{35}$. Humans are at the heart of the healthcare industry. Likewise, the most important factor in disasters is the people ${ }^{22,36}$. Almost all disaster risk reduction studies are carried out to protect human health. The Sendai Framework for Disaster Risk Reduction considers the health sector as a key component to strengthen disaster risk reduction actions. Populations and states need to improve their capacities and capabilities to cope with health risks associated with all types of hazards, emergencies, and disasters ${ }^{36}$. These strengthening efforts include the provision of safe waste management, safe drinking water, first and emergency aid in the pre-hospital area, clear energy needs, resilient hospitals, safe patient transport system, psychosocial support services, emergency immunization action planning, hospitals and trauma centers, and disease observation and early warning systems.

The basic strategy of disaster mitigation is risk assessment, risk reduction, and insurance against risk ${ }^{37}$. In disaster health services, the risk is associated with the health care system during and after any disaster-causing event ${ }^{29}$.

Risk reduction is described as extensive actions to be carried before disasters to prevent diseases, injuries, and deaths and constrain structural losses ${ }^{38}$. The prevention and protection approach within the scope of public health is evaluated in the hazard mitigation dimension of disaster risk management. The steps taken for harm reduction of potential hazards were the disaster preparedness sequence. Disasters have social and financial consequences, as well as death, illness, injury, and psychological effects. Therefore, carrying out studies in the principles of harm reduction for disasters is imperative $^{39}$.

\section{Global Developments and Framework Action Plans}

Approximately 30 years ago, policymakers worldwide collaborated to formalize the relationship between the disaster management process and health, sustainable development, and disaster management ${ }^{40}$. The action plans and strategies developed as a result of these meetings contributed to the global doctrine formation for disaster risk management for all sectors ${ }^{40}$. The International Decade for Natural Disaster Risk Reduction was declared by the UN in the early 1990s to explain the significance of disaster risks to the international community and to raise awareness. In December 1999, the International Strategy for Disaster Reduction was established at the UN General Assembly to build disaster resilience of nations, organizations, and societies, with the idea that development is fully significant in disaster reduction. At the World Conference on Disaster Risk Reduction held in Kobe, Japan in 2005, global strategies were announced by 168 countries with a guide titled Hyogo Framework for Action 2005-2015: Building the Resilience of Nations and Communities to Deal with Disasters. The Hyogo Framework reflected interventions, which were focused at the local, national, regional, and 
global levels with a comprehensive and holistic approach to support disaster risk reduction efforts. The Third World Conference on Disaster Risk Reduction, organized by the UN in Sendai, Japan in 2015, was an important breaking point on a global scale in disaster medicine and health. As the final declaration of the Sendai conference, the framework actions for disaster risk reduction between 2015-2030 were determined by the member states. The booklet titled "Sendai Framework for Disaster Risk Reduction 2015-2030" contains important global targets for disaster medicine as follows ${ }^{39}$ :

(1) Significantly reduce global disaster mortality by 2030 and reduce the global mortality rate by 100,000 in 10 years compared to 2020-2030 and 2005-2015 (18/a).

(2) Significantly reduce the number of people affected by disasters globally by 2030 and reduce the proportion of people affected globally by 100,000 in 10 years compared to 2020-2030 and 2005-2015 (18/b).

(3) Prevent damage to critical infrastructures, including health and education facilities, and the interruption of essential services and increase their resilience by 2030 $(18 / d)^{4}$.

Strengthened health services and increased disaster resilience are strongly emphasized within the framework action plans of the UN for disaster risk reduction ${ }^{39}$. A study comparing the global disaster risk reduction frameworks in Yokohama (1996), Hyogo (2005), and Sendai (2015) in disaster medicine/health revealed that the Sendai framework mentioned the concept of disaster medicine for the first time ${ }^{42}$. In the light of this concept, which is clearly expressed in the Sendai Framework for Disaster Risk Reduction, worldwide institutional studies are increasing. Disaster medicine continues to advance its scientific foundations, increasing the resilience of primary, secondary, and tertiary healthcare services, understanding disaster risks and developing safe behavior by healthcare staff, and improving disaster medicine education and training capacity (Table 1). Health resilience is strongly emphasized at local, regional, and national levels (Table 1). Disaster risk reduction strategies and plans should be developed in an applicable, holistic, and comprehensive manner.

Within the objectives of the Sendai Framework for Disaster Risk Reduction, strong progression is necessary, starting with the basic education and training of the fundamental components of disaster medicine.

\section{World Health Organization and Disaster Risk Management}

The focus of the $13^{\text {th }}$ General Program of Work (GPW13) was to create meaningful and broad-scale impact at the country level to promote health, improve health security, and serve vulnerable communities. The main premise of the GPW13 was to reduce the risks and impacts of all hazards. The World Health Organization (WHO) created a thematic platform to work in cooperation and coordination with both the health sector and all other relevant sectors, which supports the implementation and guidance of the Sendai framework, the Sustainable Development Goal objectives, the Paris Agreement, the International Health Regulations, and other WHO regional and global solutions ${ }^{41}$.

The main objective of the "Health Emergency and Disaster Risk Management Framework" guide published in 2019 by the $13^{\text {th }}$ WHO, which determined the 5-year strategic direction of WHO for the 2019-2023 period, was to emphasize the importance of prevention, preparedness, and resilience together with intervention and improvement efforts to protect health and save lives $^{36}$. This framework aimed to strengthen the capacity of the health sector and other health related sectors to combat the health effects of all kinds of emergencies and disasters and reduce the health risks of possible future events ${ }^{36}$. The importance of a multi-sectoral approach at local, regional, national, and international levels was emphasized for this objective. For countries to make this framework operational at the national level, the following are among the key features: (1) accelerate the "National Action Plan for Health Safety" process, (2) strengthen the all hazards approach in all studies, (3) transition from an event-based to a risk-based approach, (4) transition from a single-institution to a holistic-society approach, and (5) a shift from a reactive to a proactive approach, from an intervention-oriented approach to risk management ${ }^{36,43}$. Many people in vulnerable groups are affected by disasters at very different rates. Particularly, the focus of these studies is women, children, people with disabilities, the elderly, immigrants, refugees, and people with chronic diseases. Health systems at all levels play a central role in managing the risks of all hazards and mitigating the consequences, both in routine and emergency situations ${ }^{36}$.

The international institutions involved in the UN Cluster in the field of humanitarian and emergency aid in the WHO's "Health Emergency and Disaster Risk 


\begin{tabular}{|c|c|}
\hline $30 / \mathrm{i}$ & $\begin{array}{l}\text { "To enhance the resilience of national health systems, including the disaster risk management integration into primary, } \\
\text { secondary, and tertiary health care, especially at the local level;" }\end{array}$ \\
\hline $30 / \mathrm{i}$ & $\begin{array}{l}\text { "To develop the capacity of health workers in understanding disaster risk and apply and implement disaster risk reduction } \\
\text { approaches in health work;" }\end{array}$ \\
\hline $30 / \mathrm{i}$ & "To promote and enhance the training capacities in the field of disaster medicine;" \\
\hline $30 / \mathrm{i}$ & $\begin{array}{l}\text { "To support and train community health groups in disaster risk reduction approaches in health programs, in collaboration } \\
\text { with other sectors, as well as in the International Health Regulations (2005) of the World Health Organization } \\
\text { implementation;" }\end{array}$ \\
\hline $30 / j$ & $\begin{array}{l}\text { "To strengthen the design and implementation of inclusive policies and social safety-net mechanisms through community } \\
\text { involvement, livelihood enhancement program integration, and access to basic health care services, including maternal, } \\
\text { newborn and child health, sexual and reproductive health, food security and nutrition, housing, and education, toward } \\
\text { the eradication of poverty to find durable solutions in the post-disaster phase and empower and assist people who are } \\
\text { disproportionately affected by disasters;" }\end{array}$ \\
\hline $30 / \mathrm{k}$ & $\begin{array}{l}\text { "People with life-threatening and chronic disease due to their particular needs should be included in the design of } \\
\text { policies and plans to manage their risks before, during, and after disasters, including the access to life-saving services;" }\end{array}$ \\
\hline $33 / \mathrm{n}$ & $\begin{array}{l}\text { "To strengthen the sustainable use and management of ecosystems and implement integrated environmental and natural } \\
\text { resource management approaches that incorporate disaster risk reduction;" }\end{array}$ \\
\hline $33 / 0$ & $\begin{array}{l}\text { "To increase business resilience and protection of livelihoods and productive assets throughout the supply chains, ensure } \\
\text { continuity of services, and integrate disaster risk management into business models and practices." }\end{array}$ \\
\hline
\end{tabular}

Management Framework" and the issues they are interested in need many different areas to be coordinated. Disaster medicine in all stages of disaster management is directly related to the organizations and most areas of interest in Figure $3^{44}$.

\section{The International Federation of Red Cross and Red Crescent Societies (IFRC) and Health Risk Reduction Studies}

The 2030 strategy plan determined by the International Federation of Red Cross and Red Crescent Societies (IFRC) aimed to raise individuals and societies to a more resilient and healthier level and increase access to the most basic health services and water, sanitation, and hygiene (WASH) facilities through national associations. During this period, the focus was on: (1) disease prevention and health promotion, (2) WASH and health care delivery, (3) WASH and health emergencies preparedness and response, (4) epidemic/pandemic preparedness and response, and (5) WASH and humanitarian diplomacy development in health ${ }^{45}$.

A cooperation protocol was signed between the WHO and IFRC on December 11, 2020, in Geneva to strengthen the EMT and health services to better respond to the health needs of the community in natural disasters and public health emergencies. The protocol aimed to increase the capacity of the IFRC Emergency Response Unit teams by harmonizing them with the classification

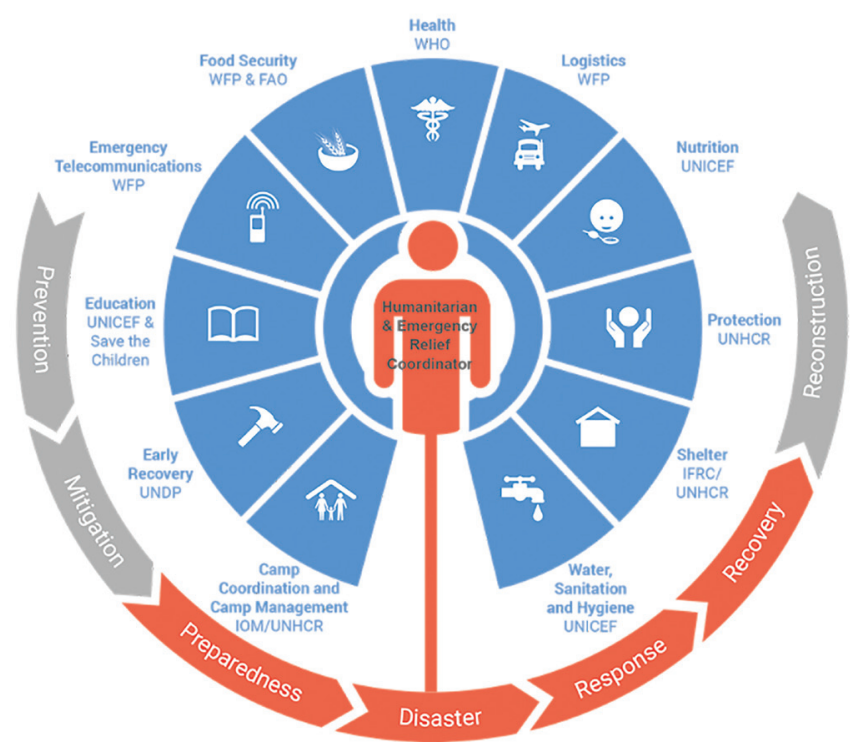

Figure 3. UN humanitarian and emergency relief cluster.

and basic standards of the WHO EMT ${ }^{46}$. The coordination and cooperation of the two important global institutions of disaster medicine during the disaster and humanitarian situations is a very important disaster risk management development.

\section{CONCLUSION}

The literature on disaster medicine continues to evolve with the interdisciplinary studies of academics, 
clinicians, practitioners, and researchers. With the Sendai Framework for Disaster Risk Reduction, which was determined globally in 2015, the development and dissemination of disaster medicine education were emphasized for the first time. The disaster medicine concept was among the disaster risk reduction policies for every country since 2015. Disaster medicine is a global, mass, administrative, and doctrinal discipline that means beyond clinical studies. As we move toward 2030, global studies should focus on health emergency and disaster risk management together with intervention in the disaster medicine concept. In this process, multidisciplinary cooperation and coordination at local, regional, and national levels should be ensured. Disaster medicine is a discipline that should work at all times for humanitarian aid, emergencies, and disasters.

Ethics Committee Approval: Not Applicable.

Informed Consent: Not Applicable.

Peer-review: Externally and internally peer-reviewed.

\section{Author Contributions}

Concept: H.K., K.K., C.C., K.A., Design: H.K., K.K., C.C., K.A., Data Collection and/or Processing: H.K., K.K., C.C., K.A., Analysis and/or Interpretation: H.K., K.K., C.C., K.A., Critical revision: H.K., K.K., C.C., K.A.

Conflict of interest: The authors declare that they have no conflict of interest.

Financial Disclosure: The authors declared that this study has received no financial support.

\section{REFERENCES}

1. Stratton SJ. Is there a scientific basis for disaster health and medicine? Prehosp Disaster Med. 2014:29:221-2.

2. Ciottone GR. Introduction to Disaster Medicine. Içinde: Ciottone's Disaster Medicine. Colorado:Elsevier; 2016.

3. Hogan D, Burstein J. General concept: basic perspective on disasters. In: Disaster Medicine. 2nd ed. Philadelphia, USA: Lippincott Williams \& Wilkins; 2007. p. 2.

4. Gunn SWA. Dictionary of Disaster Medicine and Humanitarian Relief. New York: Springer; 2013.

5. Wang Z-G, Zhang L, Zhao W-J. Emergency medicine for disaster rescue. Chin J Traumatol. 2015;18:311-3.

6. Manni C, Magalini S. Disaster medicine: a new discipline or a new approach? Prehosp Disaster Med. 1989;4:167-70.

7. Eryılmaz M. Afet Tanımı. İçinde: Afet Tıbbı. 2. basım. Ankara: Ünsal Yayınları; 2007. s. 7-21.

8. Ragazzoni L, Ingrassia PL, Ripoll A, Hubloue I, Debacker M, Della Corte F. European master in disaster medicine: Impact analysis on students' professional career. J Emerg Med. 2014;46:285-6.
9. Hubloue I, Debacker M. Education and research in disaster medicine and management: inextricably bound up with each other. Eur J Emerg Med. 2010;17:129-30.

10. Kocak H. Chapter 25 - The Role of Disaster Medicine in Disaster Management and Preparedness. In: Integrated Disaster Science and Management. Oxford/Amsterdam, Cambridge: Elsevier; 2018. p. 42331.

11. Suner S. History of disaster medicine. Turk J Emerg Med. 2015;15(Suppl 1):1-4.

12. Stehrenberger CS, Goltermann S. Disaster medicine: genealogy of a concept. Soc Sci. 2014;120:317-24.

13. Keim M. Managing health in disasters. Lancet. 2003;362:2029.

14. WADEM. Assocation Overview. About. 2021 Last Accessed Date: 04.07.2021. Available from: https://wadem.org/about/associationoverview/.

15. Altıntaş KH. Avrupa Afet Tıbbı Master Programı/European Disaster Medicine Master Program. İçinde: Eryılmaz M, Dizer U, editörler. Afet Tıbbı/Disaster Medicine. 2. basım. Ankara: Ünsal Yayınları; 2007. s. 147-52.

16. Altıntaş KH. Afetlerde Sağlık Yönetimi Yüksek Lisans Programı/ Health Management in Disasters Master. Içinde: Eryılmaz M, Dizer U, editörler. Afet Tıbbı/Afet Tıbbı. 2. basım. Ankara: Ünsal Yayınları; 2007. s. $153-8$.

17. Bezmialem Vakif University. Disaster Medicine Doctorate Program. Bologno Web Page University of Bezmialem Vakif. 2014 Last Accessed Date: 04.07.2021. Available from: https://obs.bezmialem.edu.tr/oibs/bologna/index.aspx? lang=en $\mathcal{C}$ curOp=showPac\& curUnit=53\& curSunit=5749.

18. Kınık K. Afet Tıbbı Anabilim Dalı Hakkında Genel Bilgiler. Last Accessed Date: 03.07.2021. Available from: https://sbe.sbu.edu.tr/ Akademik/AfetTibbiAnabilimDaliGenelBilgiler.

19. Ege University Information Package (2019). Ege University Institute of Health Sciences. Master Degrees. Accessed Date: 21 October 2021. Available from: https://ebp.ege.edu.tr/DereceProgramlari/Detay/2/611 61/8282/932001?lang=en-US

20. Hou SK, Lv Q, Ding H, et al. Disaster medicine in China: present and future. Disaster Med Public Health Prep. 2018;12:157-65.

21. Avegno J, Elder J. 215 - Emergency medical services and disaster medicine. In: Adams J, editor. Emergency Medicine: Clinical Essentials. 2. ed. Philedephia: Elsevier Saunders; 2013. p. 1774-82.

22. Altıntaş KH. Afetler ve afet tıbbı. Içinde: Akın L, Güler Ç, editors. Halk Sağlığı Temel Bilgiler Ankara: Hacettepe University Press; 2012. s. 1106-31.

23. Noji EK. Disaster epidemiology. Emerg Med Clin N Am. 1996;14:28999.

24. Çalişkan C. Chapter 5 - Winter Storms. In: Samui P, Kim D, Ghosh C, editors. Integrating Disaster Science and Management: Global Case Studies in Mitigation and Recovery. Amsterdam: Elsevier; 2018. p. 78.

25. Wolfe RE. Role of emergency medicine in disaster management. In: Ciottone's Disaster Medicine [Internet]. Amsterdam: Elsevier; 2016. p. 20-6.

26. Rifino JJ, Mahon SE. Role of emergency medical services in disaster management and preparedness. In: Ciottone's Disaster Medicine. Amsterdam: Elsevier; 2016. p. 13-9.

27. Boyd A, Chambers N, French S, Shaw D, King R, Whitehead A. Emergency planning and management in health care: priority research topics. Health Systems. 2014;3:83-92. 
28. Altıntaş KH. Afet ve afet tıbbı ile ilgili kavramlar. İçinde: HAMER Acil ve Afet Durumlarında Sağlık Yönetimi. Ankara: Hacettepe Üniversitesi Yayınları; 2013. s. 13-25.

29. Jaiswal R, Donahue J, Reilly MJ. Disaster risk management. In: Ciottone's Disaster Medicine Amsterdam: Elsevier; 2016. p. 167-77.

30. James JJ, Benjamin GC, Burkle FM, Gebbie KM, Kelen G, Subbarao I. Disaster medicine and public health preparedness: a discipline for all health professionals. Disaster Med Public Health Prep. 2010;4:102-7.

31. CRED. Human Cost of Disasters (2000-2019). 2020. Report No.: 61.

32. Ahmed I. Disaster Risk Management Framework. In: International Training Workshop on Disaster Risk \& Environmental Management. Malaysia: Melaka; 2008.

33. Othman SH, Beydoun G, Sugumaran V. Development and validation of a Disaster Management Metamodel (DMM). Inf Process Manag. 2014;50:235-71.

34. Dar O, Buckley EJ, Rokadiya S, Huda Q, Abrahams J. İntegrating health into disaster risk reduction strategies: key considerations for success. Am J Public Health. 2014;104:1811-6.

35. Aitsi-Selmi A, Egawa S, Sasaki H, Wannous C, Murray V. The Sendai Framework for Disaster Risk Reduction: Renewing the Global Commitment to People's Resilience, Health, and Well-being. Int J Disaster Risk Sci. 2015;6:164-76.

36. WHO. Health emergency and disaster risk management framework. 2019 Last Accessed Date: 09.12.2020. Available from: https://apps. who.int/iris/handle/10665/326106

37. Ardalan A, Ordun CY, Riley JM. Public Health and Disasters. Ciottone's Disaster Medicine. Amsterdam: Elsevier; 2016. p. 6-12.
38. Gougelet RM. Disaster Mitigation. Ciottone's Disaster Medicine. Amsterdam: Elsevier; 2016. p. 160-6.

39. UNISDR. Sendai Framework for Disaster Risk Reduction 2015 - 2030. Sendai Framework for Disaster Risk Reduction 2015-2030. Kobe, Hyogo, Japan; 2015.

40. Keim M. Managing disaster-related health risk: a process for prevention. Prehosp Disaster Med. 2018;33:326-34.

41. Wright N, Fagan L, Lapitan JM, et al. Health emergency and disaster risk management: five years into implementation of the Sendai framework. Int J Disaster Risk Sci. 2020;11:206-17.

42. Koçak H, Kara M, Görün M. Birleşmiş Milletler afet risk azaltımı çerçeve eylem planlarının nitel olarak incelenmesi ve karşılaştırılması. In: Disiplinlerarası Afet Yönetimi Araștırmaları. İzmir: Birleșik Matbacılık.; 2017. p. 151-64.

43. Achour N, Pascale F, Price ADF, et al. Learning lessons from the 2011 Van Earthquake to enhance healthcare surge capacity in Turkey. Environ Hazards. 2016;15:74-94.

44. UN OCHA. What is the Cluster Approach? [İnternet]. Humanitarian Response. Last Accesed Date: 15.05.2021. Available from: https:// www.humanitarianresponse.info/en/coordination/clusters/whatcluster-approach

45. IFRC. FRC Health and Care Framework 2030 The IFRC's contribution to healthier, more resilient communities and individuals. 2020 s. 1-27. Available from: https://reliefweb.int/report/world/ifrc-health-andcare-framework-2030-ifrc-s-contribution-healthier-more-resilient.

46. IFRC. WHO, IFRC sign memorandum of understanding on emergency medical teams. IFRC. 2020 Last Accessed Date: 15.05.2021. Available from: https://media.ifrc.org/ifrc/press-release/ifrc-signmemorandum-understanding-emergency-medical-teams/ 